\title{
Nineteenth-
}

Century

Music Review

\section{Volume 4, Issue 1}




\section{Nineteenth-Century Music Review}

\section{VOLUME 4, ISSUE 1 2007}

\section{ASHGATE}

Published in association with the Centre for Nineteenth-Century Music, Durham University, UK 
Letters to the Editor For any communication concerning published articles or reviews, please send letters by email or hard copy to the General Editor:

Dr Bennett Zon

School of Music

Durham University

Palace Green

Durham DH1 3RL

England

Email: bennett.zon@durham.ac.uk

Subscriptions For the latest information about the price of the journal and details of how to subscribe, please contact:

Nicky Staszkiewicz

Ashgate Publishing Limited

Gower House

Croft Road

Aldershot

Hants GU11 3HR

England

Tel: $+44(0) 1252351804$

Fax: $+44(0) 01252351839$

Email: journals@ashgatepublishing.com

\section{Themed Issues}

The General Editor of Nineteenth-Century Music Review encourages proposals from individuals with ideas for themed issues, involving the commissioning of up to six main articles per issue, as well as one or more review articles for coverage of books, CDs and scores. Those applying to the journal for this purpose should initially provide the General Editor with a statement of no more than 500 words, outlining the thematic nature of the proposed issue, the names of contributing authors along with a working title for their papers, and a timetable for submission of work.

Proposers of themed issues work alongside the General Editor, and are designated Guest Editors. They are responsible for commissioning, organizing and preparing articles for publication, as well as working closely with review editors to locate suitable material and authors for relevant sections of the journal. Review sections of themed issues are not exclusively thematicized, and tend towards a balance of half themed, and half general material.

Articles commissioned for themed issues follow the same process of peerreview as general issues. No guarantee of publication can be given to specially commissioned authors. 


\title{
Nineteenth-Century Music Review
}

\author{
General Editor \\ Bennett Zon \\ Book Reviews Editor \\ Anna Celenza \\ CD Reviews Editor \\ Jeremy Dibble \\ Score Reviews Editor \\ Stephen Downes
}

\section{Editorial Board}

Dr Bennett Zon, Durham University

UK (General Editor)

Professor Anna Celenza, Georgetown University, USA (Book Reviews

Editor)

Professor Jeremy Dibble, Durham University (CD Reviews Editor)
Dr Stephen Downes, University of Surrey, UK (Scores Reviews Editor) Professor William Weber, California State University, Long Beach, USA

Dr Phyllis Weliver, Wilkes University, USA

\section{Advisory Board}

\section{Dr Rosamund Bartlett}

Professor Andrew Bowie, Royal Holloway, University of London, UK

Dr Geoffrey Chew, Royal Holloway, University of London, UK

Professor John Deathridge, King's College, University of London, UK

Professor Annegret Fauser, University of North Carolina, Chapel Hill, USA

Dr Peter Franklin, University of Oxford, UK

Dr Sophie Fuller

Professor Lydia Goehr, Colombia University, USA

Professor Thomas Grey, Stanford University, USA
Professor Hervé Lacombe, Université Rennes 2 - Haute Bretagne, France Professor Roberta Marvin, University of Iowa, USA

Professor Simon McVeigh, Goldsmiths College, University of London, UK

Professor Julian Rushton, University of Leeds, UK

Professor Jim Samson, Royal Holloway, University of London, UK Professor Manuela Schwartz, Hochschule Magdeburg/Stendal (FH), Germany

Professor Nicholas Temperley, University of Illinois, USA 
All rights reserved. No part of this publication may be reproduced, stored in a retrival system, or transmitted in any form or by any means, electronic, mechanical, photocopying, recording or otherwise, without the prior permission of the publisher.

Published by

Ashgate Publishing Limited

Ashgate Publishing Company

Gower House

Suite 420

Croft Road

101 Cherry Street

Aldershot

Burlington, VT 05401-4405

Hants GU11 3HR

USA

England

This journal is the successor of the Music Review, founded by the late Geoffrey Sharp, which then continued for many years under the ownership of the late A.F. Leighton-Thomas.

Ashgate website: http:/ / www.ashgate.com

ISSN: 1479-4098

Typeset by IML Typographers, Birkenhead, Merseyside

Printed by MPG Books Ltd, Bodmin, Cornwall 


\section{Contents}

Volume 4, Issue 1

Notes on Article Contributors

ix

\section{Articles}

Brian Alegant and Don McLean

On the Nature of Structural Framing

Anastasia Siopsi

Theorizing 'Death': The Meaning of Negation as a Hegelian

Inheritance in Richard Wagner's Musik als Idee

Marian Wilson Kimber

Victorian Fairies and Felix Mendelssohn's A Midsummer Night's Dream

in England

Thomas Muir

'Old Wine in New Bottles': Renaissance Polyphony in the English

Catholic Church during the Nineteenth and Early Twentieth Centuries

Donald C. Seibert

The Enchantress and Problems of Pacing in the Operas of Tchaikovsky:

An Informal Interview with David Lloyd-Jones

\section{REviews}

Review Article

Byron Adams

Elgar Studies

Book Reviews

Marianne Betz

The Cambridge Companion to the String Quartet edited by Robin Stowell

Ryan Ebright

Making Words Sing: Nineteenth- and Twentieth-Century Song by

Jonathan Dunsby

Helen Julia Minors

Musical Encounters at the 1889 Paris World's Fair by Annegret Fauser

Patricia Puckett

Landscape and Gender in Italian Opera: The Alpine Virgin from Bellini

to Puccini by Emanuele Senici

Books Received 
CD Reviews

William A. Everett

York Bowen: Viola Concerto in C minor op. 25; Cecil Forsyth: Viola

Concerto in $\mathrm{G}$ minor. Lawrence Power va, BBC Scottish Symphony

Orchestra, Martyn Brabbins cond

Margaret Notley

Brahms: Cello Sonata No. 1 in E minor op. 38, Cello Sonata No. 2 in

F major op. 99; Dvořák: Waldesruhe op. 68, no. 5, Rondo in G minor op. 94; Suk: Ballade in D minor op. 3, no. 1, Serenade in A major op. 3, no. 2. Steven Isserlis $v c$, Stephen Hough $p f$

Julian Horton

Bruckner: String Quintet in F major*, String Quartet in C minor.

Leipzig String Quartet, Andreas Seidel vn, Tilman Büning vn, Ivo

Bauer $v a$, Matthias Moosdorf $v c$, with Hartmut Rohde $v a$

Lois Fitch

Busoni: Lustspiel-Ouvertüre for Orchestra op. 38, Indianische

Fantasie for Piano and Orchestra op. 44, Gesang vom Reigen der

Geister op. 47, Die Brautwahl op. 45. Nelson Goerner $p f$, BBC

Philharmonic Orchestra, Neeme Järvi cond

Stephen Downes

Karłowicz: Returning Waves op. 9, A Sorrowful Tale op. 13, Episode at a Masquerade op. 14. BBC Philharmonic Orchestra, Gianandrea

Noseda cond

Alexandra Wilson

Puccini: La Bohème, sung in German (Munich 1951). Trude Eipperle

(Mimi), Karl Terkal (Rodolfo), Wilma Lipp (Musetta), Alfred Poell

(Marcello), Karl Hoppe (Schaunard), Hans-Hermann Nissen (Colline),

Choir and Orchestra of the Bavarian Radio, Clemens Krauss cond

Michael Spitzer

Rimsky-Korsakov: Four Operas: The Snow Maiden* - Fairy-tale Opera

in a Prologue and Four Acts, The Golden Cockerel - Fairy-tale Opera in

Three Acts\#, The May Night-Opera in Three Acts $\mathbb{1}$, Boyarinya Vera

Sheloga* - Opera in One Act*. Bulgarian Radio Symphony Orchestra*, Stoyan Angelov cond, Kölner Rundfunk-Sinfonie-OrchesterपI,

Alexander Lazarew cond, Sofia National Opera Orchestra\#, Dimiter Manolov cond

CDs Received

Score Reviews

Lars Franke

Hermann Goetz, Der Widerspänstigen Zähmung, Study Score

Peter Franklin

Franz Schreker, Lieder (Gesang und Klavier) with an introduction

and editorial notes by Christopher Hailey 
Stephan D. Lindeman

Felix Mendelssohn Bartholdy, Concerto in E minor for Violin and

Orchestra, op. 64, 1844/1845, edited by R. Larry Todd

Lisa Feurzeig

Franz Schubert, Lieder, vol. 1, edited by Walther Dürr

Scores Received

183

Guidelines for Contributors 